\title{
FAMÍLIA E HOMOSSEXUALISMO: ANÁLISE HERMENÊUTICA DO CONCEITO DE FAMÍLIA NO CASO ATALA RIFFO E MENINAS VS. CHILE, CORTE INTERAMERICANA DE DIREITOS HUMANOS, ̀̀ LUZ DA TEORIA HERMENÊUTICA DE HANS-GEORG GADAMER
}

\author{
FAMILY AND HOMOSSEXUALISM: HERMENEUTIC ANALYSIS OF THE \\ CONCEPT OF FAMILY AT ATALA RIFFO AND CHILDREN VS. CHILE CASE, \\ INTER AMERICAN COURT OF HUMAN RIGHTS, ANALYSED BY HANS-GEORG \\ GADAMER'S HERMENEUTIC TEORY
}

${ }^{1}$ Thiago Augusto Galeão De Azevedo

\section{RESUMO}

O presente artigo tem como objeto de estudo o conceito de família adotado no caso Atala Riffo e Meninas Vs. Chile, Corte Interamericana de Direitos Humanos, à luz da hermenêutica gadameriana. Para tanto, optou-se por uma exposição factual do referido caso, seguida de uma exposição teórica acerca dos principais institutos hermenêuticos gadamerianos, quais sejam: tradição, situação hermenêutica, história efeitual, fusão de horizontes e linguagem; para ao final analisar hermeneuticamente a sentença proferida pela Corte, no que concerne à adoção de uma concepção de família no citado caso. Têm-se como objetivos, inicialmente, expor os fatos próprios ao caso, descrevendo os aspectos processais que o conduziram à Corte Interamericana, além de expor os direitos, e seus respectivos artigos, atinentes ao conceito de família, considerados violados pelo Estado do Chile; conceituar os principais institutos da hermenêutica gadameriana, a fim de fornecer o substrato teórico necessário para a análise hermenêutica final; analisar hermeneuticamente a sentença proferida pela Corte, atinente à sustentação de um conceito de família no caso em questão, a partir dos referidos conceitos hermenêuticos gadamerianos. Tais objetivos possuem a finalidade de permitir a realização de análise hermenêutica sobre a sentença proferida no caso, pela Corte, no que se refere à consideração de que a relação formada pela Sra. Atala Riffo, sua companheira, suas três filhas menores e seu filho mais velho, constitui uma entidade familiar, uma vida familiar.

Palavras-chave: Hermenêutica, Orientação sexual, Discriminação, Guarda, Entidade familiar

\footnotetext{
${ }^{1}$ Mestrando em Direito, Políticas Públicas e Desenvolvimento Regional pelo Centro Universitário do Estado do Pará - CESUPA, Pará (Brasil). Professor do Centro Universitário do Estado do Pará - CESUPA, Pará (Brasil). E-mail: thiagogaleao@hotmail.com
} 


\begin{abstract}
This article has as his main object of study the family concept adopted in the case Atala Riffo and Girls Vs. Chile, Inter-American Court of Human Rights, analysed by Gadamer's hermeneutics. Therefore, we opted for a factual exposition of that case, followed by a theoretical exposition on the main hermeneutical gadamerianos institutes, namely: tradition, hermeneutics situation, effectual history, fusion of horizons and language; to the end hermeneutically analyze the judgment delivered by the Court, concerning the adoption of a family of design in that case. There have as objectives, initially, set out the facts themselves to that case, describing the processais aspects which led to the Inter-American Court, besides exposing rights, and their respective articles, relating to the concept of family, considered violated by the State of Chile; conceptualize the main Institutes Gadamerian hermeneutic in order to provide the substrate necessary for the theoretical hermeneutic final analysis; analyze hermeneutically the judgment rendered by the Court, relating to the support of a family concept in this case, from such concepts of Gadamer's hermeneutics. These objectives have the purpose of allowing the completion of the hermeneutical analysis of the judgment in the case, by the Court, with regard to the consideration that the relationship formed by Ms. Atala Riffo, his mate, her three young daughters and her eldest son, constitutes a family entity, a family life.
\end{abstract}

Keywords: Hermeneutics, Sexual orientation, Discrimination, Guard, Family entity 


\section{INTRODUÇÃO}

O presente artigo tem como objeto de estudo o conceito de família adotado no caso Atala Riffo e Meninas Vs. Estado do Chile, da Corte Interamericana de Direitos Humanos. Trata-se de um caso no qual se discute a concessão do direito de guarda à mãe, Sra. Atala, em relação à suas três filhas de um antigo relacionamento.

Entretanto, o que enseja a discussão acerca da concessão do citado direito é o fato da Sra. Atala, após romper com o seu ex-marido, ter se relacionado com a Sra. Ramón, sua companheira, com a qual passou a coabitar, junto com as suas três filhas e seu filho mais velho. Neste contexto, o presente artigo tem como escopo a análise do conceito de família adotado no referido caso pela Corte Interamericana de Direitos Humanos, a partir de uma análise hermenêutica gadameriana.

Para tanto, inicialmente, expor-se-á as questões factuais atinentes ao caso, analisando-se os aspectos procedimentais que ensejaram a condução do referido à Corte Interamericana de Direitos Humanos. Posteriormente, ainda na seção de exposição factual, analisar-se-á a sentença proferida pela Corte, no âmbito dos direitos e artigos considerados violados pelo Estado do Chile, atinentes ao conceito de família, principalmente no que concerne ao direito à não discriminação e à vida privada e familiar.

Em seguida, expor-se-á os principais argumentos sustentados pelos advogados das partes e pela Comissão Interamericana de Direitos Humanos, assim como as considerações proferidas pela Corte Interamericana no que concerne ao conceito de família adotado no caso em análise.

Fornecido o substrato factual necessário, realizar-se-á a exposição e conceituação de conceitos hermenêuticos, à luz de Hans-Georg Gadamer, quais sejam: tradição, situação hermenêutica, história efeitual, fusão de horizontes e linguagem; a fim de fornecer a base teórica necessária para a realização da análise hermenêutica sobre a sentença proferida pela Corte no presente caso.

Por fim, analisar-se-á hermeneuticamente, à luz da teoria hermenêutica de Gadamer, a sentença proferida pela Corte Interamericana de Direitos Humanos, concernente ao conceito de família adotado no caso Atala Riffo e Meninas Vs. Estado do Chile, utilizando-se para tanto os citados conceitos hermenêuticos. 


\title{
1 ASPECTOS FACTUAIS DO CASO ATALA RIFFO E MENINAS VS. ESTADO DO CHILE
}

Inicialmente, expor-se-á as questões fáticas atinentes ao caso Atala Riffo e Meninas $V s$. Estado do Chile, a fim de fornecer o substrato factual necessário para o entendimento da análise hermenêutica a ser realizada sobre a sentença proferida pela Corte Interamericana de Direitos Humanos, no que concerne ao conceito de família adotado no caso em questão.

Em setembro de 2010, a Comissão Interamericana de Direitos Humanos apresentou uma demanda contra o Estado do Chile, com fulcro nos arts. 51 e 61 da Convenção Americana de Direitos Humanos. A petição inicial foi apresentada diante da referida Comissão em 24 de novembro de 2004, por Karen Atala Riffo, representada por advogados da Associação Liberdades Públicas, da Clínica de Ações de Interesse Público da Universidade Diego Portales e da Fundação Ideas.

\begin{abstract}
Artigo 51 - 1. Se, no prazo de três meses, a partir da remessa aos Estados interessados do relatório da Comissão, o assunto não houver sido solucionado ou submetido à decisão da Corte pela Comissão ou pelo Estado interessado, aceitando sua competência, a Comissão poderá emitir, pelo voto da maioria absoluta dos seus membros, sua opinião e conclusões sobre a questão submetida à sua consideração. 2. A Comissão fará as recomendações pertinentes e fixará um prazo dentro do qual o Estado deve tomar as medidas que lhe competirem para remediar a situação examinada. 3. Transcorrido o prazo fixado, a Comissão decidirá, pelo voto da maioria absoluta dos seus membros, se o Estado tomou ou não medidas adequadas e se publica ou não seu relatório.
\end{abstract}

Artigo 61 - 1. Somente os Estados Partes e a Comissão têm direito de submeter caso à decisão da Corte. 2. Para que a Corte possa conhecer de qualquer caso, é necessário que sejam esgotados os processos previstos nos artigos $48^{\circ}$ a $50^{\circ}$. (OEA, 1969).

Em 23 de julho de 2008, a comissão aprovou a admissibilidade (informe de admissibilidade No. 42/08), e em dezembro de 2009, emitiu o relatório de mérito No. 139/09, em conformidade com o art. 50 da Convenção Americana. Em 17 de setembro de 2010, devido a Comissão Interamericana de Direitos Humanos considerar que o Estado do Chile não havia dado cumprimento às recomendações presentes no referido relatório de mérito, submeteu o presente caso à jurisdição da Corte Interamericana.

Artigo 50 - 1. Se não se chegar a uma solução, e dentro do prazo que for fixado pelo Estatuto da Comissão, esta redigirá um relatório no qual exporá os fatos e suas conclusões. Se o relatório não representar, no todo ou em parte, o acordo unânime dos membros da Comissão, qualquer deles poderá agregar ao referido relatório seu voto em separado. Também se agregarão ao relatório as exposições verbais ou escritas que houverem sido feitas pelos interessados em virtude do inciso 1 , e, do artigo $48^{\circ}$. (OEA, 1969). 
Trata-se de um caso que envolve a responsabilidade internacional do Estado do Chile pelo tratamento discriminatório e pela interferência arbitrária na vida privada e familiar do indivíduo, no caso a Sra. Atala, devido à orientação sexual da referida, fazendo com que esta perdesse a guarda de suas filhas M., V. e R.

Expostos os aspectos procedimentais próprios ao caso, passar-se-á à análise factual detalhada do mesmo. Em 29 de março de 1993, a Sra. Atala contraiu matrimônio com Ricardo Jaime López, relacionamento que ensejou frutos, as crianças M., V. e R., nascidas em 1994, 1998 e 1999, respectivamente. A Sra. Atala antes de contrair o referido matrimônio já possuía um filho, maior de idade, Sergio Vera Atala, fruto de um relacionamento anterior.

Em março de 2002, o referido casal acordou em finalizar o seu matrimônio através de uma separação de fato, ficando decidido que as três filhas do casal ficariam sob a guarda da Sra. Atala, na cidade de Villarrica, com regime de visita semanal do pai na cidade de Temuco.

Entretanto, a situação fática ensejadora da presente problemática paira sobre o relacionamento da Sra. Atala com a sua companheira, a Sra. Emma de Ramón. Elas passaram a morar juntas em novembro de 2002, junto com as três filhas da Sra. Atala, decorrentes de seu antigo casamento, e com o seu filho mais velho. Neste contexto, em 14 de janeiro de 2003, Ricardo López ingressou com uma ação de guarda perante o juizado de menores de Villarrica, sob a tese de que o desenvolvimento físico e emocional das crianças estaria em perigo por estas estarem sob a guarda de sua mãe, na casa onde a mesma coabita com a sua companheira.

Alegou-se que a Sra. Atala não se encontrava capacitada para zelar e cuidar das três crianças, uma vez que a sua nova opção sexual, junto com o fato de a mesma estar convivendo com a sua parceira na mesma casa onde habitam suas filhas, estariam produzindo conseqüências danosas ao desenvolvimento das menores, o que representaria a falta de interesse da mãe em zelar e proteger o desenvolvimento integral de suas filhas.

Outra concepção sustentada pelo Sr. López é a de que a tendência do ordenamento jurídico em atribuir, destaca-se, "normalidade" à casais do mesmo sexo contribuía para a desnaturalização do sentido de casal humano, homem e mulher. Alterando, desta forma, o sentido natural da família, uma vez que afetava os valores fundamentais à mesma, considerada representante do "núcleo central da sociedade". Ademais, alegou-se que a opção sexual exercida pela Sra. Atala alteraria a convivência, destaca-se, "sana, justa e normal" que as menores teriam direito. 
Por fim, o Sr. Lopez argumentou que se deveria levar em consideração, também, as conseqüências biológicas para as menores, no sentido de que a convivência com um casal formado por lésbicas, no plano das enfermidades, exporia as referidas crianças, de forma permanente, ao surgimento de herpes e AIDS (sida).

A Sra. Atala sustentou que as alegações feitas sobre a sua identidade sexual em nada possuem relação com a sua função e papel de mãe, que por isso deveria ficar fora da lide instaurada, uma vez que conjugalidade ou opção sexual não são extensivas a relações de parentalidade, que era a matéria discutida nos autos. Neste sentido, a Sra. Atala alegou que nem o Código Civil chileno, tampouco a Lei de Menores de Idade contemplam como causa de “inabilitação parental” a opção sexual.

O caso foi coberto por uma série de meios de comunicação. Pelas notícias vinculadas por estes e pelo alegado uso indevido de recursos do Tribunal Penal de Villarrica, no qual a Sra. Atala possuía o cargo de juíza, em 19 de março de 2003, o Pleno da Corte de Apelações de Temuco designou o Ministro Lenin Lillo para fazer uma visita extraordinária ao referido Tribunal Penal, diante do procedimento disciplinar instaurado contra a Sra. Atala.

Em 10 de março de 2003, a advogada do Sr. López ingressou com uma ação de guarda provisória, com a finalidade de obter a guarda de suas filhas antes do desfecho do processo de guarda principal. Na citada ação foi destacado o suposto caráter egoísta da Sra. Atala, decorrente da preferência da referida em buscar a sua felicidade, através de sua relação amorosa "lesbiana", em detrimento do cumprimento do papel dos pais, que inclui a capacidade funcional da maternidade, conforme sustentado em tal ação. Ademais, a supracitada advogada alegou, destaca-se, o direito das filhas de viverem com um pai e com uma mãe de sexos distintos. O advogado da Sra. Atala rechaçou tais alegações.

O juizado de menores de Villarrica, em 02 de maio de 2003, concedeu a guarda provisória ao pai das crianças e regulou o direito de visita da mãe aos filhos, mesmo considerando que não há como presumir causas de falta de habilidade legal da mãe.

Em cumprimento ao que foi determinado em tal ação de guarda provisória, em 08 de maio de 2003, a Sra. Atala entregou suas filhas ao Sr. López. Em resposta à decisão, a Sra. Atala requereu o afastamento do juiz titular de Menores de Villarrica, a fim de que este não siga o processo de guarda. Em 14 de maio de 2003, o referido juiz se absteve de intervir no citado processo.

Em 29 de outubro de 2003, a juíza substituta do Juizado de Menores de Villarrica concedeu a guarda das menores à mãe, a Sra. Atala. Na referida sentença, rechaçou-se a ação 
de guarda, sustentando-se que com base nas provas existentes, restou comprovado que a orientação sexual da demandada não representava um impedimento para o desenvolvimento da maternidade responsável, ademais que não representava nenhuma patologia psiquiátrica que impedisse o exercício do papel materno, e que não existem indicadores que permitam presumir a existência de causas de inabilidade materna para assumir os cuidados pessoais das menores.

A referida sentença concluiu, também, que a coabitação entre as filhas da Sra. Atala e sua companheira não representaria um fato que prejudicasse o bem-estar das menores. Ademais, que a homossexualidade não consiste em uma patologia e que a demanda não apresentava nenhuma contra-indicação do ponto de vista psicológico para o exercício do papel materno.

Quanto à análise da inabilidade da Sra. Atala para ser mãe, informações das entidades Organização Panamericana de Saúde, do Departamento de Psicologia da Universidade do Chile e da Faculdade de Educação da Pontifícia Universidade Católica do Chile; tenderam positivamente à mãe das crianças, no sentido de afastar o homossexualismo da patologia, destacando, ademais, que a capacidade de amar e cuidar de filhos não possui relação com a identidade sexual, nem mesmo com as opções sexuais dos pais.

Analisou-se, também, os exames psicológicos realizados nas crianças, na demandada e no demandante, concluindo-se que a coabitação da Sra. Atala com a sua companheira, na mesma casa em que mora com suas filhas, não representa uma causa de inabilidade pessoal para o exercício do cuidado para com as referidas, além de que não se acredita na existência de fatos concretos que representem o prejuízo do bem-estar das menores, derivado da citada coabitação.

O Tribunal de Menores de Villarrica ordenou, assim, a entrega das crianças à mãe, Sra. Atala, em 18 de dezembro de 2003. Entretanto o pai, Sr. López, interpôs um recurso de Apelação e, posteriormente, um pedido provisional de não inovação, argumentando que o cumprimento da sentença de $1^{\circ}$ grau ocasionaria uma mudança radical e violenta do status quo das menores de idade.

Em 24 de novembro de 2003, a Corte de Apelações de Temuco concedeu a ordem de não inovação, requerida pelo pai das crianças. Contra esta ordem não inovatória, a Sra. Atala entrou com uma queixa disciplinar contra os integrantes da referida Corte, alegando causas de desqualificação e inabilidade dos mesmos. A Corte Suprema de Justiça do Chile, entretanto, 
decidiu, em 02 de julho de 2004, que não houve falta ou abuso por parte dos ministros objetos da citada queixa disciplinar.

Em 30 de março de 2004, a Corte de Apelações de Temuco confirmou a sentença apelada pelo pai das crianças, ratificando as considerações próprias da $1^{\mathrm{a}}$ instância. Quanto à ordem de não inovar concedida em 24 de novembro de 2003, declarou-se a mesma sem efeito.

Em 05 de abril de 2004, o pai das crianças, inconformado com a decisão retro, entrou com um "recurso de queixa" contra os juízes da Corte Americana de Temuco, solicitando a manutenção provisória das crianças sob a sua guarda. Tal recurso foi pautado na suposta primazia dos interesses da mãe em detrimento dos interesses das menores. A Corte Suprema concedeu a ordem de não inovar, requerida em 07 de abril de 2004.

Em 31 de maio de 2004, a referida Corte Suprema, em uma votação dividida em três votos contra dois, acolheu o "recurso de queixa", concedendo a guarda definitiva ao pai das crianças. Tal decisão foi pautada na ideia de que o interesse dos menores deve prevalecer sobre os interesses da mãe, sustentando que o art. 225 do Código Civil chileno não é uma norma absoluta, podendo ser relativizada, quando prevê que em casos dos pais viverem separados o cuidado pessoal dos filhos é atributo da mãe.

A corte suprema concluiu, através de prova testemunhal, que a relação homossexual da mãe das menores ensejou uma deterioração do entorno social, familiar e educacional, fato este que poderia ocasionar uma discriminação social. Ademais, conclui-se, também, por meio do depoimento dos funcionários da casa, que as meninas apresentam confusão em relação à sexualidade materna, confusão esta auferida através das percepções dos referidos acerca de jogos e atitudes das menores.

A Suprema Corte sustentou, também, o entendimento de que a Sra. Atala, ao assumir o seu relacionamento homossexual, estaria sobrepondo o seu interesse pessoal sobre os interesses das menores, além do destaque com relação aos efeitos que tal relação homossexual pode causar no bem-estar e no desenvolvimento psíquico e emocional das filhas, diante da carência da figura do pai do sexo masculino. Em relação ao referido posicionamento do judiciário chileno, a Comissão da Corte Interamericana de Direitos Humanos alegou que o presente caso está eivado de discriminação e de uma ingerência arbitrária na vida privada e familiar da Sra. Atala.

Sobre as alegações da citada Comissão, o Estado do Chile argumentou que a orientação sexual da Sra. Atala não foi o fundamento das resoluções da ação, e sim a análise de quem tinha mais condições de cuidar das menores, sustentando-se que a orientação sexual foi 
considerada, mas como um elemento pontual, sendo o melhor interesse da criança o fundamento das referidas resoluções.

A Corte Interamericana de Direitos Humanos, por sua vez, considera que na ação de guarda se debateu a orientação sexual da Sra. Atala, a sua personalidade, os danos presumidos causados às filhas da referida e a alegada preferência que a Sra. Atala deu aos seus interesses pessoais em detrimento dos interesses das menores. Ressalta-se, entretanto, que o citado Tribunal não funciona como uma quarta instância, tendo como propósito investigar se as autoridades judiciais afetaram ou não obrigações estipuladas na Convenção.

\subsection{Conceito De Família: Análise Da Sentença Proferida Pela Corte Interamericana De Direitos Humanos}

Expostas as questões factuais, partir-se-á para a análise da sentença proferida no caso em tela, pela Corte Interamericana de Direitos Humanos, datada de 24 de fevereiro de 2012. Entretanto, destaca-se que diante da extensão e da multiplicidade de direitos considerados violados na referida sentença, optou-se, para a concretização do objetivo do presente ensaio, pela realização de um corte metodológico, corte este realizado no âmbito dos direitos e artigos violados, analisando-se, especificamente, as violações atinentes ao conceito de família.

Ressalta-se que a sentença em análise foi proferida pelos juízes Diego García-Sayán (presidente), Manuel E. Ventura Robles (vice-presidente), Leonardo A. Franco, Margarette May Macaula, Rhadys Abreu Blondet e Alberto Pérez Pérez; havendo apenas um voto parcialmente dissidente, o proferido pelo citado juiz Alberto Pérez, conforme será analisado na presente seção.

Ao se analisar a destacada sentença, pode-se perceber, atinente a cada direito, a violação de um conjunto de artigos da Convenção Americana de Direitos Humanos, artigos os quais passam a ser especificados a seguir.

Inicialmente, no âmbito do direito à Igualdade e da Não Discriminação, a Corte responsabilizou o Estado do Chile pela violação do art. 24, relacionado ao art. 1.1 da Convenção Americana de Direitos Humanos, atinentes aos prejuízos sofridos pela Sra. Atala. Em relação aos prejuízos ocasionados às crianças M., V. e R., constatou-se a responsabilidade do referido Estado pela violação do art. 24, relacionado aos artigos 19 e 1.1 da Convenção. 
Artigo 24 - Igualdade perante a lei Todas as pessoas são iguais perante a lei. Por conseguinte, têm direito, sem discriminação, a igual proteção da lei.

Artigo 1 - Obrigação de respeitar os direitos 1. Os Estados Partes nesta Convenção comprometem-se a respeitar os direitos e liberdades nela reconhecidos e a garantir seu livre e pleno exercício a toda pessoa que esteja sujeita a sua jurisdição, sem discriminação alguma por motivo de raça, cor, sexo, idioma, religião, opiniões políticas ou de qualquer outra natureza, origem nacional ou social, posição econômica, nascimento ou qualquer outra condição social.

Artigo 19 - Direitos da criança Toda criança tem direito às medidas de proteção que a sua condição de menor requer por parte da sua família, da sociedade e do Estado. (OEA, 1969).

Quanto à violação do direito à vida privada e familiar, a Corte constatou a violação do art. 11.2, relacionado com o art. 1.1 da Convenção, em relação aos prejuízos sofridos pela Sra. Atala. Quanto às menores e à Sra. Atala, conjuntamente, decidiu-se pela responsabilização do Estado do Chile pela violação dos arts. 11.2 e 17.1, relacionados com o art. 1.1 da Convenção.

Artigo 11 - Proteção da honra e da dignidade. 2. Ninguém pode ser objeto de ingerências arbitrárias ou abusivas em sua vida privada, na de sua família, em seu domicílio ou em sua correspondência, nem de ofensas ilegais à sua honra ou reputação.

Artigo 17 - Proteção da família 1. A família é o elemento natural e fundamental da sociedade e deve ser protegida pela sociedade e pelo Estado. (OEA, 1969).

Conforme ressaltado anteriormente, no presente caso, houve apenas um voto parcialmente dissidente, o do juiz ad hoc Alberto Pérez Pérez. O seu voto diverge quanto ao ponto resolutivo ${ }^{\circ}$ 4, que explicita a violação dos arts. 11.2 e 17.1 da Convenção Americana de Direitos Humanos. Para o referido juiz, dever-se-ia ter mencionado apenas o art. 11.2, e não também o art. 17.1, acreditando não ser necessário, tampouco prudente, a declaração de sua violação.

Tal discordância é decorrente da concepção, própria do referido juiz, de que o art. 11.2 consiste em um aspecto autônomo e específico do dever geral de proteção, de modo que não se faz necessária a invocação do citado artigo junto com o art. 17 da Convenção. Para tal juiz, a previsão de que os mesmos fatos violam um dever geral e um dever específico não altera a natureza, tampouco a gravidade da violação, nem mesmo conduz à aplicação de reparações distintas, o que faz o juiz em questão entender desnecessária a declaração de violação do art. 17.1 da Convenção.

Conforme ressaltado anteriormente, a partir do corte metodológico realizado, fixouse como ponto hermenêutico, no presente ensaio, o conceito de família, conceito este que será o elemento a ser averiguado na próxima seção, que se destina a analisar as alegações sustentadas 
pelos advogados da Sra. Atala e do Sr. López, e as considerações efetuadas pela Corte Interamericana de Direitos Humanos sobre o assunto, argumentos e considerações estas que constam na sentença em análise.

1.1.1 Argumentos Sustentados Acerca Do Conceito De Família Na Sentença Proferida Pela Corte Interamericana De Direitos Humanos

Conforme destacado anteriormente, optou-se pela realização de um corte metodológico, a fim de que o objetivo do presente artigo possa ser concretizado. Neste sentido, no que concerne ao conceito de família, expor-se-á as alegações e considerações efetuadas acerca do tema, citadas na sentença em análise. Tal exposição abordará dois eixos atinentes ao assunto: o direito à Igualdade e à Não Discriminação, e a violação do direito à Vida Privada e à Vida Familiar.

As referidas considerações e alegações acerca de tal ponto hermenêutico possuem como finalidade o fornecimento do substrato material necessário para a realização da análise hermenêutica final do mesmo, assim como será necessário a exposição e o estudo dos conceitos hermenêuticos indispensáveis para a concretização da citada análise, conceitos estes a serem expostos e analisados na seção ulterior, à luz da hermenêutica gadameriana.

No âmbito do direito à Igualdade e à Não Discriminação, atinente à violação dos arts. 24 e 1.1 da Convenção, a Corte alegou a existência de um amplo reconhecimento dos Estados americanos de que a discriminação com base na orientação sexual é proibida. Alegando, ademais, que a decisão da Suprema Corte de Justiça chilena, em sede da já exposta ação de guarda, teve com fundamento a orientação sexual da Sra. Atala, uma vez que determinou a perda da guarda pela referida enquanto esta convivesse com uma pessoa do mesmo sexo, assim como a decisão em sede da ação de guarda provisória.

Os representantes da Sra. Atala alegaram que os Estados assinaram a Convenção Americana de Direitos Humanos com uma cláusula aberta quanto à discriminação, o que os impede de alegar que o nível de seu desenvolvimento político social não lhe permite compreender que a orientação sexual representa uma das razões proibitivas do ato de discriminação.

Sobre o referido contexto, o Estado do Chile argumentou que o Sistema Interamericano de Direitos Humanos requer credibilidade e confiança dos seus Estados membros, com o fim de destacar que uma relação de confiança recíproca pode ser afetada se a Corte impele um rol 
regulador sobre o conceito de discriminação, sem outorgar efeito aos sentidos majoritários próprios de cada Estado.

Ademais, o Estado do Chile concorda que os Estados membros consentiram em se obrigar pelas disposições da Convenção, quando a assinaram, entretanto, sustenta que os Estados prestaram o seu consentimento a uma idéia de direitos humanos, que incluía certos tipos de violação, mas não outras que no tempo da assinatura não existiam, referindo-se à discriminação baseada na orientação sexual.

Neste contexto, o Estado em questão ressalta que em 2004, ano em que a sentença da Suprema Corte chilena foi prolatada, a orientação sexual não era uma "categoria" consensual. Com base nesta concepção, alega-se que não é procedente realizar exigências em relação à decisão proferida pela referida Suprema Corte com base em uma "categoria" que não é objeto de um consenso interamericano.

A fim de resolver as citadas controvérsias levantadas pelo Estado do Chile, a Corte interamericana teceu as suas considerações. Sustentou-se, inicialmente, que a Corte, assim como o Tribunal Europeu de Direitos Humanos, estabeleceu que os Tratados de direitos humanos são instrumentos vivos, cuja interpretação tem que acompanhar a evolução dos tempos e das condições de vida atuais. Em relação à referida interpretação evolutiva, sustentou-se que esta está associada às regras gerais de interpretação consagradas no art. 29 da Convenção Americana e as estabelecidas pela Convenção de Viena, sobre os Direitos dos

Tratados.

\begin{abstract}
Artigo 29 - Normas de interpretação. Nenhuma disposição desta Convenção pode ser interpretada no sentido de: a. permitir a qualquer dos Estados Partes, grupo ou pessoa, suprimir o gozo e exercício dos direitos e liberdades reconhecidos na Convenção ou limitá-los em maior medida do que a nela prevista; b. limitar o gozo e exercício de qualquer direito ou liberdade que possam ser reconhecidos de acordo com as leis de qualquer dos Estados Partes ou de acordo com outra convenção em que seja parte um dos referidos Estados; c. excluir outros direitos e garantias que são inerentes ao ser humano ou que decorrem da forma democrática representativa de governo; e d. excluir ou limitar o efeito que possam produzir a Declaração Americana dos Direitos e Deveres do Homem e outros atos internacionais da mesma natureza. (OEA, 1969).
\end{abstract}

Neste contexto, a Corte passa a analisar a expressão "qualquer outra condição social" do art. 1.1 da Convenção, que, em sua concepção, deve ser interpretada sempre à luz da alternativa mais favorável à tutela dos direitos protegidos pelo referido Tratado, seguindo-se o princípio da norma mais favorável ao homem.

A corte sustenta que o rol do art. 1.1 da Convenção não é taxativo, mas meramente enunciativo, justamente porque a expressão "qualquer outra condição social" expressa a 
inserção de outras "categorias" de discriminação que não estivessem expressamente previstas. A referida expressão deve ser interpretada pela Corte à luz da perspectiva mais favorável à pessoa e à evolução dos direitos fundamentais, no direito internacional contemporâneo.

A Corte Interamericana estabeleceu, neste sentido, que a orientação sexual e identidade de gênero são “categorias" protegidas pela Convenção, baseando-se, para tanto, nas obrigações gerais de respeito e garantia do estabelecido no art. 1.1 da Convenção Americana, nos critérios de interpretação firmados no art. 29 da Convenção, no estipulado pela Convenção de Viena acerca do Direito dos Tratados, nas resoluções da Assembléia Geral da OEA e nos entendimentos firmados pelo Tribunal Europeu de Direitos Humanos e pelos Organismos das Nações Unidas.

Desta forma, através da Convenção, nenhuma norma, decisão ou prática de direito interno, emitida por autoridades estatais ou particulares, pode restringir, de qualquer modo, os direitos de um indivíduo em razão de sua orientação sexual. Neste sentido, desconsiderou-se o argumento do Estado do Chile, de que não havia um consentimento interno sobre a discriminação em razão da orientação sexual, uma vez que tal argumento não é válido para legitimar a negação dos direitos humanos de tais indivíduos ou mesmo para perpetuar e reproduzir a discriminação histórica que os referidos indivíduos sofreram.

O referido argumento de ausência de consenso não exime o Tribunal da obrigação de decidir, pois ao decidir tal Tribunal deve se remeter única e exclusivamente às obrigações internacionais contraídas pelos Estados membros, através da assinatura da Convenção.

Por sua vez, podem-se destacar as considerações realizadas pela Corte acerca do direito à vida privada e à vida familiar. A Comissão, assim como os representantes da Sra. Atala, alegaram que o direito à vida privada e à vida familiar foram violados pelo Estado do Chile, identificando-se, neste sentido, a violação dos arts. 11.2 e 17 da Convenção. Alega-se que os referidos direitos se estendem às relações entre os membros de uma família e às relações afetivas do projeto de vida de cada integrante da mesma.

Os representantes da Sra. Atala alegaram que não há um conceito único de família, no sentido de que a referida, suas filhas, seu filho mais velho e a Sra. Ramón formavam um núcleo familiar que foi afastado, rompido, por decisões baseadas na orientação sexual da Sra. Atala.

O Estado do Chile, por sua vez, defendeu que em uma ação de guarda, faz parte do papel do juiz investigar todas as condições de exercício do referido poder entre os pais, a fim de garantir o interesse superior da criança. Neste sentido, cabe à natureza da própria ação e ao papel 
do juiz investigar questões íntimas dos pais, defendendo-se, portanto, a não violação pela Suprema Corte chilena, assim como pelos demais Tribunais chilenos, do art. 11.2 da Convenção. Em relação a tal contexto, a Corte concluiu pela vulnerabilidade do art. 11.2, em relação ao art. 1.1 da Convenção Americana, por parte do Estado do Chile, em prejuízo da Sra. Atala.

No âmbito da vida familiar, destacou-se que um dos argumentos centrais da decisão da Suprema Corte chilena, assim como do Juizado de Menores de Villarrica, foi a convivência da Sra. Atala com a sua parceira do mesmo sexo. Neste contexto, a Corte reafirmou que o art. 11.2 da Convenção Americana está relacionado com o direito de proteção à família e a viver nela, levando-se em consideração o art. 17 da Convenção, que prega que o Estado está obrigado a dispor e executar medidas de proteção às crianças, mas principalmente de proporcionar o desenvolvimento e o fortalecimento do núcleo familiar.

Neste sentido, a Corte interamericana considera que a padronização do conceito de família consistiria em uma ingerência arbitrária contra a vida privada, violando-se o art. 11.2 da Convenção, assim como representaria um impacto ao núcleo familiar, de acordo com o que o art. 17 da Convenção preceitua.

A Corte Interamericana considerou, portanto, a presença, no presente caso em análise, de um núcleo familiar, protegido pelos arts. 11.2 e 17.1 da Convenção Americana, tendo em vista a existência de uma convivência, um contato freqüente e uma proximidade pessoal e afetiva entre a Sra. Atala, sua companheira, suas filhas e seu filho mais velho.

Portanto, a Corte Interamericana de Direitos Humanos concluiu que os fundamentos utilizados pela Suprema Corte chilena e pelo Juizado de Menores de Villarrica foram medidas inidôneas de proteção do interesse superior das menores, medidas estas que causaram a separação da família constituída pela Sra. Atala, sua companheira, suas filhas e seu filho mais velho; consistindo em uma interferência arbitrária na vida privada e familiar da Sra. Atala e de suas filhas.

Desta feita, a Corte declarou que o Estado do Chile violou os arts. 11.2 e 17.1, em relação ao art. 1.1 da Convenção Americana, em prejuízo de Karen Atala Riffo e das crianças M., V. e R. Em relação às menores, a violação à vida familiar incide também sobre o art. 19 da Convenção, uma vez que foram afastadas de maneira injustificada de seu entorno familiar.

Pode-se identificar, neste sentido, que para Corte Interamericana de Direitos Humanos a relação constituída pela Sra. Atala, sua companheira, suas três filhas e seu filho mais velho constitui, destaca-se, uma relação familiar. Neste sentido, identifica-se o conceito de família como um ponto hermenêutico na referida sentença, através dos dois eixos sustentadores 
do mesmo: o direito à Igualdade e à Não Discriminação, e o direito à Vida Privada e à Vida Familiar.

Uma vez apresentadas as alegações e considerações acerca do tema, partir-se-á para o estudo e a exposição de conceitos hermenêuticos, à luz da hermenêutica gadameriana, a fim de que se possa produzir o substrato teórico para a análise hermenêutica final, na qual serão identificados os fundamentos utilizados na referida sentença para basear as considerações da Corte sobre o conceito de família adotado no caso em questão.

\section{CONCEITOS HERMENÊUTICOS, À LUZ DE HANS-GEORG GADAMER}

A presente seção se destinará ao fornecimento do substrato teórico necessário para a realização da análise hermenêutica da sentença proferida pela Corte Interamericana de Direitos Humanos no caso em análise, à luz da teoria de Hans-Georg Gadamer, atinente à adoção de um conceito de família.

Para tanto, na presente seção, serão expostos os conceitos de tradição, história efeitual, situação hermenêutica, fusão de horizontes e linguagem; a partir da hermenêutica gadameriana, propiciando a realização da referida análise.

\subsection{Tradição E Preconceitos}

Inicialmente, deve-se elucidar o conceito de Tradição em Gadamer, que, à luz do referido autor, possui como essência o ato de "continuar transmitindo naturalmente aquilo que é transmitido" (1999, p. 21).

Em Gadamer, a tradição possui um viés positivo, oposto à lógica difundida pelo iluminismo, que possui como consequiência a submissão da autoridade à razão e, conseqüentemente, a submissão da tradição, tendo em vista que esta era considerada a fonte última da autoridade e, mesmo, uma forma de autoridade, fonte de preconceitos, preconceitos estes decorrentes da autoridade, entendidos como imposições à compreensão.

Gadamer critica que o iluminismo deformou o conceito de autoridade, tornando-se o contrário à razão e liberdade, conceito este que pode ser traduzido em uma obediência cega a algo. Neste contexto, o referido autor destaca o que entende por autoridade (1999, p. 419): 
Todavia, não é isso a essência da autoridade. Na verdade, a autoridade é, em primeiro lugar, um atributo de pessoas. Mas a autoridade das pessoas não tem seu fundamento último num ato de submissão e de abdicação da razão, mas num ato de reconhecimento e de conhecimento: reconhece-se que o outro está acima de nós em juízo e perspectiva e que, por consequiência, seu juízo precede, ou seja, tem primazia em relação ao nosso próprio.

Neste sentido, Gadamer destaca o caráter positivo da autoridade, relatando que a autoridade é própria de certas pessoas, baseada em um ato de conhecimento e reconhecimento do outro, da superioridade desse outro, no âmbito de juízos e perspectivas. Tal superioridade influencia na aceitação da primazia do juízo da autoridade sobre o nosso próprio juízo. A autoridade possui uma visão mais ampla, mais geral, e consagrada, o que fazem esta ser considerada melhor.

Percebe-se, a partir de tais concepções, o papel da autoridade na compreensão. O juízo defendido pela autoridade, quando reconhecida, está relacionado à idéia de que este não é uma "arbitrariedade irracional". Entretanto, não significa que o juízo da autoridade deve ser incorporado, pelo indivíduo, de forma absoluta e automática, e sim algo que pode ser analisado, inspecionado.

Desta forma, a autoridade está relacionada à compreensão, no sentido de que a essência desta está ancorada em uma teoria de preconceitos, em que estes, fundamentados por uma autoridade, ganham a legitimidade de, pelo menos, serem analisados, investigados.

Trata-se da análise da legitimidade dos preconceitos, a fim de se examinar se estes são arbitrários ou não. A referida análise da legitimidade de tais preconceitos, conforme já destacado anteriormente, possuem uma nítida relação com a compreensão, no sentido de que as concepções prévias do intérprete não podem ser arbitrárias, sua legitimidade deve ser investigada, caso contrário não haverá compreensão.

Neste contexto, para Gadamer toda compreensão é preconceituosa, por estar eivada de opiniões e preconceitos próprios do intérprete, anteriores ao ato de compreensão do texto. Identificadas tais opiniões e preconceitos, Gadamer destaca que não é o esvaziamento destes que deve ser feito, no sentido de esquecê-las, mas a potencial abertura à alteridade textual, ou seja, a possibilidade "intercambial” entre as concepções próprias, de conteúdo e preconceitos do intérprete, com a opinião de outrem ou do texto.

Desta forma, o ato de compreender é incompatível com a entrega, ab initio, às próprias opiniões prévias e preconceitos. A compreensão está relacionada com o ato libertário de permitir que o texto, por si, possa transmitir algo ao intérprete. Trata-se de uma abertura para a alteridade proporcionada pelo texto. 
Destaca-se, desta forma, a importância da consciência das referidas concepções prévias ao texto, tendo em vista que é através desta que o intérprete poderá controlar tais concepções e preconceitos, seguindo-se o que requer, de acordo com Gadamer (1999), a "consciência histórico-hermenêutica", ou seja, a compreensão orientada por uma consciência metódica, que permite a identificação dos preconceitos e concepções prévias do intérprete e, a partir da citada identificação, o controle destas, diante do seu anonimato, conforme destaca Gadamer (1999, p. 403):

\begin{abstract}
A compreensão somente alcança sua verdadeira possibilidade, quando as opiniões prévias, com as quais ela inicia, não são arbitrárias. Por isso faz sentido que o intérprete não se dirija aos textos diretamente, a partir da opinião prévia que lhe subjaz, mas que examine tais opiniões quanto a sua legitimação, isto é, quanto a sua ordem e validez.
\end{abstract}

Finalmente, será através deste controle que se poderá chegar a uma compreensão correta, a partir da própria coisa. Trata-se, portanto, de uma consciência metódica, que permite afastar aquilo que possa impedir a compreensão a partir da coisa.

Assim, destaca-se a existência de preconceitos legítimos, que contribuem para a compreensão. Tais preconceitos, por sua natureza, abalam a referida lógica negativa iluminista. Desta forma, o citado autor destaca (1999, p.418):

Se existem também preconceitos justificados e que possam ser produtivos para o conhecimento, o problema da autoridade volta a nos ser colocado. Assim, as conseqüências radicais do Aufklarung, que se encontram ainda na fé metódica de Schlerermacher, não são sustentáveis.

Neste sentido, a verdade, a compreensão correta, buscada pela hermenêutica, apenas poderá ser alcançada com o reconhecimento de que toda compreensão é marcada por concepções prévias, por preconceitos, que precisam ser identificados pelo intérprete, seguido da necessidade de controle destes, para que a alteridade textual possa ser recepcionada, permitindo-se, desta forma, o "intercâmbio", o "diálogo" entre os preconceitos do intérprete, conscientes e controlados, e o texto, possibilitando-se, assim, uma compreensão correta a partir da coisa.

Portanto, a partir de Gadamer, pode-se perceber que razão absoluta não existe, uma vez que não produzimos compreensões livres de preconceitos e concepções prévias, tendo em vista que a tradição possui uma autoridade anônima, que permeia nossos comportamentos e instituições.

Gadamer destaca que a história não pertence a nós, e sim nós que pertencemos a ela, no sentido de que somos permeados pelos institutos existentes à época, como a família, a 
sociedade e o Estado. Desta forma, não é possível termos uma compreensão isenta de preconceitos, da tradição, descontextualizada, uma vez que, conforme destaca Gadamer (1999, p. 415), a razão não é independente:

\begin{abstract}
Achar-se imerso em tradições significará realmente em primeiro plano estar submetido a preconceitos e limitado na própria liberdade? Não é certo, antes, que toda existência humana, mesmo a mais livre, está limitada e condicionada de muitas maneiras? E se isso é assim, então a idéia de uma razão absoluta não é uma possibilidade da humanidade histórica. Para nós a razão somente existe como real e histórica, isto significa simplesmente: a razão não é dona de si mesma, pois está sempre referida ao dado no qual se exerce.
\end{abstract}

Desta forma, a superioridade iluminista da razão em relação à tradição pode ser considerada ilegítima, através das concepções sustentadas por Gadamer, tendo em vista que não é possível sustentar uma compreensão isenta de autoridade e tradição. Além de que esta não representa uma imposição, e sim um momento de liberdade e, mesmo, da história.

\title{
2.2 História Efeitual, Situação Hermenêutica E Fusão De Horizontes
}

Gadamer destaca que um pensamento verdadeiramente histórico não pode deixar de levar em consideração a sua própria historicidade. Apenas desta forma abandonará o "fantasma de um objeto histórico" (Gadamer, 1999, p. 448), tendo em vista que este é objeto de uma investigação progressiva, possibilitadora do conhecimento do outro no objeto, diferente do próprio.

Neste sentido, um processo de busca de uma verdade histórica não pode apenas considerar o corte histórico do seu objeto, metodologicamente. Não se pode esquecer o caráter histórico da compreensão. Desta forma, o objeto histórico, na verdade, não é um objeto, mas uma unidade formada pela realidade da história e a realidade do compreender histórico. A esta concepção se dá o nome de "história efeitual", conforme destaca Gadamer (1999, p.449):

\begin{abstract}
A consciência histórica tem de se conscientizar de que, na suposta imediatez com que se orienta para a obra ou para a tradição, está sempre em jogo esse outro questionamento, ainda que de uma maneira despercebida e, por conseqüência, incontrolada. Quando procuramos compreender um fenômeno histórico a partir da distância histórica que determina nossa situação hermenêutica como um todo, encontramo-nos sempre sob os efeitos dessa história efeitual. Ela determina de antemão o que se mostra a nós de questionável e como objeto de investigação, e nós esquecemos logo a metade do que realmente é, mais ainda, esquecemos toda a verdade deste fenômeno, a cada vez que tomamos o fenômeno imediato como toda a verdade.
\end{abstract}

Neste sentido, a partir das noções da história efeitual, Gadamer comenta que quando se pretende compreender um fenômeno histórico de imediato, acaba-se por limitar a compreensão, uma vez que os pontos questionáveis do objeto de compreensão são criados ou 
mesmo moldados pela tradição e preconceitos. Pode-se inferir, portanto, que a história de uma obra, de um objeto, é construída a partir das interpretações que são emitidas, ao longo do tempo, pelo homem. Desta forma, o indivíduo, ao interpretar a obra de forma imediata, estará limitado pelas interpretações que já foram feitas anteriormente, distanciando-se da verdade do objeto.

Gadamer preleciona que "A consciência da história efeitual é em primeiro lugar consciência da situação hermenêutica" (1999, p.451). A referida afirmação pode ser analisada através da concepção de que a situação não é algo que se está diante, no sentido de que podemos identificá-la de modo objetivo, pelo contrário, o intérprete está na citada situação.

A consciência da situação hermenêutica segue a referida linha lógica, no sentido de que o intérprete sempre está numa situação, sendo a sua tarefa tomar consciência da mesma, que nunca acontecerá por completo.

A situação hermenêutica está relacionada à tradição, a qual se procura entender, no sentido de que o intérprete não está diante da tradição, mas inserido nela, uma vez que esta é um processo em movimento e expansão. Assim, pode-se inferir que a relação entre história efeitual e consciência da situação hermenêutica está baseada na ideia de que o intérprete é um ser pertencente à tradição.

A consciência do caráter histórico da compreensão (consciência da história efeitual) está relacionada à tradição, da qual o intérprete faz parte. Portanto, a compreensão da história efeitual tem como primeiro nível a compreensão da situação hermenêutica, porque o intérprete deve refletir, tomar consciência da situação em que está inserido para interpretar um objeto histórico, a partir da historicidade de sua compreensão.

A consciência da situação hermenêutica tem o papel de limitar um viés de concepção, equiparando-se a um horizonte, no sentido de delimitar o que pode ser compreendido a partir de certo ponto, de uma concepção. Neste sentido, destaca Gadamer (1999, p.452):

Todo presente finito tem seus limites. Nós determinamos o conceito da situação justamente pelo fato de que representa uma posição que limita as possibilidades de ver. Ao conceito da situação pertence essencialmente, então, o conceito do horizonte. Horizonte é o âmbito de visão que abarca e encerra tudo o que é visível a partir de um determinado ponto. [...] ter horizontes significa não estar limitado ao que há de mais próximo, mas poder ver para além disso. Aquele que tem horizontes sabe valorizar corretamente o significado de todas as coisas que caem dentro deles, segundo os padrões de próximo e distante, de grande e pequeno. A elaboração do horizonte de questionamento correto para as questões que se colocam frente à tradição. 
Neste contexto, pode-se destacar a figura do horizonte relacionado à compreensão histórica, no sentido de compreender o objeto histórico por si e não a partir de padrões pessoais e preconceitos contemporâneos, e sim a partir do que Gadamer chama de "seu próprio horizonte histórico" (1999, p. 452).

Pode-se destacar a existência de dois horizontes diversos, o horizonte daquele que compreende (consciência da situação hermenêutica) e o horizonte histórico ao qual o intérprete pretende se deslocar. Neste contexto, levando-se em consideração os referidos horizontes, o ato de compreender, para Gadamer, é o processo de fusão de horizontes. Acerca dos citados, destaca tal autor (1999, p. 458):

\begin{abstract}
O projeto de um horizonte histórico é, portanto, só uma fase ou momento na realização da compreensão, \& não se prende na auto-alienação de uma consciência passada, mas se recupera no próprio horizonte compreensivo do presente. $\mathrm{Na}$ realização da compreensão tem lugar uma verdadeira fusão horizôntica que, com o projeto do horizonte histórico, leva a cabo simultaneamente sua suspensão.
\end{abstract}

Ressalta-se, entretanto, que não existe um horizonte do presente em si mesmo, uma vez que este se forma em constante relação com o horizonte do passado, assim como não existem horizontes históricos a serem explorados, uma vez que ambos estão irradiados um pelo outro, pois o compreender é o processo de fusão desses horizontes, que são presumivelmente considerados por si próprios.

Assim, o horizonte histórico é um projeto que representa uma fase no processo de compreensão, não se limitando em uma consciência passada, uma vez que se utiliza o próprio horizonte compreensivo do presente. Assim, pode-se inferir que a compreensão é composta pela fusão do horizonte relativo àquele que compreende, com o horizonte histórico.

\title{
2.3 Linguagem
}

Inicialmente, deve-se considerar que a experiência hermenêutica se realiza no chamado "modo" da linguagem, ou seja, é através da linguagem que a experiência hermenêutica se concretiza. A citada experiência está fundamentada no caráter do acontecer da linguagem, ou seja, no fato de que na relação entre tradição e intérprete há uma espécie de conversação. Nesta, Gadamer cita que algo acontece, no sentido de que a consciência do intérprete não consegue definir aquilo que a tradição exprime, tampouco se pode descrever adequadamente a referida tradição.

A partir do ponto de vista do intérprete, o acontecer assume o sentido de que não é o citado intérprete que busca o seu objeto, tampouco tem como definir, metodologicamente, a 
descrição do referido e o que este quis dizer. Já através da perspectiva do “objeto”, o conteúdo da tradição ganha ênfase, desenvolvendo-se possibilidades de sentido e de investigação variadas, novas e ampliadas de forma inovadora pelo receptor.

Desta forma, percebe-se que a tradição não é algo imediatamente perceptível, uma vez que "Toda apropriação da tradição é historicamente distinta das outras, e isso não quer dizer que cada uma seja apenas uma acepção distorcida daquela: Cada uma é, antes, a experiência de um 'aspecto’ da própria coisa.” (1999, p.684).

Neste contexto, sustenta-se que tradição é linguagem, no sentido de que é o ouvir que faz esta ser compreendida, conforme destaca Gadamer (1999, p. 671):

\begin{abstract}
Essa comunicação lingüística entre presente e tradição é, como já mostramos, o acontecer que em toda compreensão abre seu caminho. A experiência hermenêutica tem de assumir, como experiência autêntica, tudo o que lhe se torna presente. Não é livre para eleger ou rejeitar previamente. Tampouco está em condições de afirmar uma liberdade absoluta nesse 'deixar as coisas como estão' que parece o específico do compreender o compreendido. $\mathrm{O}$ acontecido que ela é não pode fazer que as coisas não tenham acontecido.
\end{abstract}

A experiência hermenêutica está relacionada ao fato de que o texto que se pretende compreender trata de uma situação que já possui opiniões prévias. Destaca-se, entretanto, que não se trata de um obstáculo à pureza da compreensão, pelo contrário, é o instrumento de atribuição de possibilidade à compreensão. É somente pela falta de uma concordância lógica e natural entre o intérprete e o texto, que se possibilita a experiência hermenêutica.

Neste sentido, destaca-se o caráter "interminavelmente" aberto de sentido. É impossível uma consciência, mesmo infinita, de uma coisa transmitida que fosse considerada eterna. Tal impossibilidade possui relação com o instituto da história efeitual, com a historicidade do compreender, na acepção da própria historicidade do compreender histórico; uma vez que não há como ter a consciência do referido objeto considerado eterno, tendo em vista que a própria historicidade da compreensão deste proporcionaria uma nova apropriação sobre o objeto, no caso a tradição.

Gadamer sustenta, portanto, que através desta relação, a experiência hermenêutica é marcada pela linguagem, conforme destaca (1999, p. 671):

\footnotetext{
Não é preciso dizer que o modo de ser da tradição não é algo imediatamente sensível. Ele é linguagem, e o ouvir que a compreende, na medida em que interpreta os textos, envolve sua verdade num comportamento para com o mundo, comportamento próprio e lingüístico. Essa comunicação lingüística entre presente e tradição é, como já mostramos, o acontecer que em toda compreensão abre seu caminho.
}

Neste sentido, o modo de ser da tradição não é imediatamente sensível. O modo de ser da tradição é lingüístico, ou seja, é a linguagem que nos fala a tradição. A partir das 
concepções do citado autor, entende-se que toda compreensão será perpassada pela linguagem, o que faz esta linguagem universal, assim como a hermenêutica, conseqüentemente. Desta forma, pode-se inferir que tudo é linguagem, uma vez que a experiência humana no mundo se dá a partir da referida. Quanto a tal caráter universal da linguagem, Gadamer destaca que (1999, p. 670):

Não há nada que não seja acessível ao ouvido através da linguagem. Enquanto nenhum dos demais sentidos participa diretamente da universalidade da experiência lingüística do mundo, já que cada um deles abarca tão somente o seu campo específico, o ouvir é um caminho rumo ao todo, porque está capacitado para escutar o logos.

Neste contexto, Gadamer sustenta o caráter especulativo da tradição, no sentido de que não é possível se delimitar um "sentido em si", uma vez que "toda apropriação da tradição é historicamente distinta das outras" (1999, p. 684). Conseqüentemente, toda interpretação, por ter como objeto a tradição, é considerada especulativa também, o que torna o seu objeto inacessível no seu próprio ser. Sobre a citada inacessibilidade no seu próprio ser, Gadamer (1999, p. 685-686) destaca:

\footnotetext{
Ser uma e a mesma coisa e, ao mesmo tempo, ser distinto, esse paradoxo aplicável a todo conteúdo da tradição põe a descoberto que toda a tradição é, na realidade, especulativa. Por isso, a hermenêutica tem que deixar o olhar atravessar o dogmatismo de todo 'sentido em si', tal como fez a filosofia crítica com relação ao dogmatismo da experiência. [...] trata-se de que toda interpretação é especulativa em sua própria realização efetiva e acima de sua autoconsciência metodológica; isso é o que emerge da linguisticidade da interpretação.

[...]

Pode-se dizer também da palavra interpretadora, como de qualquer outra palavra em que se realiza o pensar, que não é objetiva enquanto tal. Como realização da compreensão ela é a atualidade da consciência da história efeitual, e como tal é verdadeiramente especulativa: é inacessível no seu próprio ser e, no entanto, devolve a imagem que se lhe oferece.
}

Neste sentido, destaca-se o centro especulativo da linguagem, tanto na linguagem da conversação, como na da interpretação. O referido caráter especulativo tem como efeito um ser que não é cópia de algo já fixado, delimitado, mas se trata de um "vir-à-fala", uma anunciação de sentido. Trata-se da ideia de que a tradição nos fala, através da linguagem. Neste contexto, o ser compreendido é linguagem.

\section{ANÁLISE HERMENÊUTICA GADAMERIANA: O CONCEITO DE FAMÍLIA ADOTADO NO CASO ATALA RIFFO E MENINAS VS. CHILE}

Conforme destacado anteriormente, iniciar-se-á a presente análise hermenêutica acerca do conceito de família adotado no caso em questão, a partir da exposição dos fundamentos utilizados na respectiva sentença da Corte Interamericana de Direitos Humanos. 
Em relação ao conceito de família, pode-se destacar o posicionamento da Organização dos Estados Americanos (OEA) e da Organização das Nações Unidas (ONU), assim como o do Tribunal Europeu de Direitos Humanos, que convergem no sentido de considerar a inexistência de um modelo, um padrão de família.

Tal noção inclusiva, sustentada principalmente pelo referido Tribunal, refere-se às relações não baseadas no matrimônio, assim como relações compostas por indivíduos do mesmo sexo. Uma criança nascida em uma relação que não seja baseada no matrimônio e/ou seja composta por indivíduos do mesmo sexo, faz parte de uma família a partir de seu nascimento, existindo entre a criança e seus pais uma vida familiar, à luz do entendimento do citado Tribunal Europeu, do qual a Corte Interamericana de Direitos Humanos expôs vários casos na sentença em análise, os quais serão expostos e analisados a seguir, conjuntamente com resoluções da OEA e ONU sobre o tema.

Neste contexto, pode-se destacar, inicialmente, o caso Marckx Vs. Bélgica, sentenciado em 1979, caso no qual o Tribunal Europeu de Direitos Humanos considerou que a distinção entre filhos legítimos e ilegítimos não era objetiva, legítima ou razoável, considerando, portanto, que a referida distinção consistia em uma discriminação. O citado caso é sucedido por outros dois do Tribunal Europeu, que corroboram o mesmo sentido, o caso Keegan Vs. Irlanda e o caso Kroon e outros Vs. Holanda, ambos sentenciados em 1994.

Destaca-se que tais casos se restringiram à questão da distinção entre filhos legítimos e ilegítimos ser considerada uma discriminação. Entretanto, em 1997, o Tribunal Europeu sentenciou o caso $\mathrm{X}, \mathrm{Y}$ e $\mathrm{Z} V s$. Reino Unido, em que se considerou a relação entre um transexual, uma mulher e uma criança, uma relação familiar, uma vida familiar. Percebe-se, portanto, uma primeira abertura do conceito de família no âmbito da sexualidade.

Em 1999, tal Tribunal sentenciou o caso Salgueiro Vs. Portugal, que inclui a orientação sexual no art. 14 da Convenção Européia. Neste sentido, o termo “qualquer outra situação" do citado artigo foi interpretado no sentido de incluir a orientação sexual, proibindo- se a discriminação pautada na referida.

\footnotetext{
Artigo 14 - Proibição de discriminação: o gozo dos direitos e liberdades reconhecidos na presente Convenção deve ser assegurado sem quaisquer distinções, tais como as fundadas no sexo, raça, cor, língua, religião, opiniões políticas ou outras, a origem nacional ou social, a pertença a uma minoria nacional, a riqueza, o nascimento ou qualquer outra situação. (TEDH, 1950).
}

No caso Fretté Vs. França, sentenciado em 2002, no qual o referido tinha o interesse de adotar uma criança, sendo homossexual e solteiro, tendo o seu pedido negado; o Tribunal Europeu não considerou que houve violação do art. 14 da Convenção, uma vez que entendeu 
que esta não garante o direito à adoção, mas condenou o Estado francês pela não garantia de um processo equitativo, pois se cerceou a manifestação de Fretté durante o processo.

No contexto do Sistema Interamericano, houve quatro resoluções sucessivas anuais aprovadas pela Assembléia Geral da Organização dos Estados Americanos (OEA), desde 2008, que versam sobre a proteção das pessoas contra o tratamento discriminatório ensejado pela orientação sexual e identidade de gênero, as quais exigem medidas concretas para uma proteção eficaz contra a discriminação.

Neste sentido, em 2008, na referida Assembléia, AG/RES. 2435 (XXXVIII-O/08), manifestou-se uma preocupação com os atos de violência e violadores dos direitos humanos relacionados, atos estes baseados na orientação sexual ou identidade de gênero da vítima.

Ainda no ano de 2008, a Assembléia Geral das Nações Unidas adotou, em 22 de dezembro, a "Declaração sobre Direitos Humanos, Orientação Sexual e Identidade de Gênero", ratificadora do Princípio da Não Discriminação, que prega a aplicação dos direitos humanos a todos os indivíduos, independente de sua orientação sexual ou identidade de gênero.

Em 2009, na referida Assembléia Geral anual dos Estados Americanos, em 04 de junho, AG/RES. 2504 (XXXIX-O/09), resolveu-se por condenar os atos de violência e as violações de direitos humanos relacionados, ensejados pela orientação sexual e identidade de gênero dos indivíduos. Ademais, resolveu-se por instar os Estados a investigarem tais atos, por tal motivação, sendo os agentes devidamente responsabilizados.

Por sua vez, em 02 de março de 2010, o Tribunal Europeu sentenciou o caso Kozak Vs. Polônia, considerando o art. 14, associado com o art. 8 da Convenção européia, para reconhecer direitos sucessórios decorrentes de relações homossexuais.

\footnotetext{
Artigo 8 - Direito ao respeito pela vida privada e familiar 1. Qualquer pessoa tem direito ao respeito da sua vida privada e familiar, do seu domić́lio e da sua correspondência. 2. Não pode haver ingerência da autoridade pública no exercício deste direito senão quando esta ingerência estiver prevista na lei e constituir uma providência que, numa sociedade democrática, seja necessária para a segurança nacional, para a segurança pública, para o bem - estar econômico do país, a defesa da ordem e a prevenção das infrações penais, a proteção da saúde ou da moral, ou a proteção dos direitos e das liberdades de terceiros. (TEDH, 1950).
}

Ainda em 2010, em 08 de junho, na já citada Assembléia Geral anual das Nações Unidas, AG/RES. 2600 (XL-O/10), condenou-se os atos violentos e a violência, nos moldes do ano anterior. Entretanto, incluiu-se a questão do ato de incitar os Estados para que tomem as medidas necessárias para a garantia de que não cometam atos de violência ou atos violadores de direitos humanos contra pessoas, devido a sua orientação sexual e identidade 
gênero, assegurando-se o acesso à justiça das vítimas de forma igualitária. Ademais, tratou-se também do incentivo aos Estados membros para que estes busquem meios para combater a discriminação baseada na orientação sexual e na identidade de gênero.

Em 24 de junho de 2010, pode-se destacar um caso paradigmático em relação ao conceito de família, o caso Schalk e Kopf Vs. Áustria, por ser o primeiro em que o Tribunal Europeu se manifestou revisando sua jurisprudência vigente, na qual era considerado que uma relação emocional e sexual entre um casal do mesmo sexo constituía apenas "vida privada", e não "vida familiar".

Assim, ao aplicar a conceituação ampla de família, tal Tribunal estabeleceu que o citado conceito inclui uma relação estabelecida de fato por um casal do mesmo sexo, assim como abarcaria a relação formada por um casal composto por parceiros de sexos diferentes, ambos os casais desfrutando do disposto no art. 8 da Convenção Européia. Percebe-se, assim, uma abertura ao conceito de família, a partir da extensão do referido conceito às relações formadas por casais do mesmo sexo, considerando que estes possuem uma vida familiar.

Em 13 de julho de 2010, o Tribunal Europeu, mais uma vez, no caso Clift Vs. Reino Unido, reiterou o entendimento de que a orientação sexual é uma "categoria" que pode ser incluída na expressão "outra situação" do artigo 14 da Convenção, considerada pessoal, diante do fato de ser inata, inerente à pessoa.

Em 22 de julho de 2010, sentenciou-se o caso P.B e J.S Vs. Áustria, no qual se reiterou a concepção de que a relação entre pessoas do mesmo sexo constitui uma vida familiar, uma família, seguindo-se o entendimento paradigmático fixado no caso Schalk e

Kopf Vs. Áustria, já exposto anteriormente.

No âmbito da inclusão da orientação sexual no termo "outra situação", do art. 14 da Convenção Européia, pode-se destacar outros dois casos sentenciados em 28 de setembro de 2010 e 21 de outubro do mesmo ano, o caso J.M Vs. Reino Unido e o caso Alekseyev Vs. Rússia, respectivamente.

Em 22 de março de 2011, foi apresentada diante do Conselho de Direitos Humanos das Nações Unidas a "Declaração conjunta de destaque dos atos de violência, e as violações de direitos humanos dirigidas contra os indivíduos por sua orientação sexual e identidade de gênero". Em 15 de junho de 2011, o referido Conselho aprovou uma resolução sobre "Direitos Humanos, Orientação Sexual e Identidade de Gênero", na qual se expressou a preocupação em relação aos atos de violência e discriminação, em todas as regiões do mundo, cometidas contra indivíduos em razão de sua orientação sexual ou identidade de gênero. 
Por fim, antes da sentença do caso em análise, Atala Riffo e Meninas Vs. Chile, citou-se na referida decisão, a resolução da OEA, na Assembléia Geral anual, celebrada em 07 de junho, AG/RES. 2653 (XLI-O/11), na qual se resolveu condenar a discriminação de pessoas por motivo de orientação sexual e identidade de gênero, e instar os Estados, dentro dos parâmetros de suas instituições jurídicas de seu ordenamento interno, a adotar medidas necessárias para prevenir, sancionar e erradicar a citada discriminação.

Trata-se da ordem cronológica dos fundamentos apresentados na sentença do caso em análise, fundamentos estes baseados nos casos do Tribunal Europeu de Direitos Humanos, e nas resoluções da OEA e da ONU.

A partir de tal contexto, pode-se perceber que os casos atinentes ao assunto são próprios do Tribunal Europeu de Direitos Humanos, por isso o caso Atala Riffo Vs. Chile se mostra paradigmático, pois se trata do primeiro caso, no âmbito da Corte Interamericana de Direitos Humanos, em que se discute o caráter familiar da relação composta por um casal formado por indivíduos do mesmo sexo, havendo filhos de um dos parceiros; e, conseqüentemente, os direitos decorrentes da referida relação.

Tal análise cronológica dos referidos fundamentos, expostos na sentença em estudo, é fundamental para a realização da análise hermenêutica que a presente seção se propõe, análise esta a ser realizada considerando os conceitos hermenêuticos expostos na seção anterior.

Destaca-se que a presente análise tem como escopo averiguar hermeneuticamente a sentença proferida pela Corte Interamericana de Direitos Humanos, atinente ao caso em questão, no âmbito da adoção de um conceito inclusivo de família, que considera a relação entre um casal do mesmo sexo, com filhos de uma das parceiras, uma entidade familiar.

Iniciando-se a referida análise hermenêutica acerca do conceito de família, a partir do caso Atala Riffo e Meninas Vs. Chile, pode-se destacar o instituto da tradição, à luz dos ensinamentos gadamerianos. Considerando que para Gadamer a tradição tem como essência a continuidade natural da transmissão daquilo que é transmitido, pode-se destacar uma primeira ressignificação do conceito de família a partir de 1979, com o caso Marckx Vs. Bélgica, paradigmático ao considerar discriminatória a segregação entre filhos legítimos e ilegítimos.

A partir da concepção de que o indivíduo não está diante da tradição, mas inserido na mesma, pode-se destacar a existência de uma tradição no sentido de considerar discriminatório o critério de legitimidade dos filhos baseado no matrimônio. Destaca-se que tal tradição não surgiu no ano de 1979, com o referido caso, mas tão somente foi 
institucionalizada pelo Tribunal Europeu de Direitos Humanos a partir do mesmo, expressando a citada ressignificação do conceito de família. Destaca-se que tal tradição foi firmada por outros casos no Tribunal em questão, como no caso Keegan Vs. Irlanda e no caso Kroon e outros Vs. Holanda.

Em 1997, pode-se perceber uma segunda ressignificação do conceito de família, quando foi sentenciado o caso X, Y, e Z Vs. Reino Unido, em que a relação entre um transexual, uma mulher e uma criança foi considerada vida familiar, uma relação familiar. Neste sentido, a partir do citado caso houve uma segunda abertura quanto ao conceito de família, alargando-se o referido instituto no que concerne à orientação sexual do indivíduo, não o restringindo apenas aos casais que seguem a lógica dominante heterossexual.

Entretanto, foi em 2010, através do caso Schalk e Kopf Vs. Áustria, que o conceito de família sofreu a ressignificação mais importante para o caso em análise, uma vez que a partir do referido se considerou que casais formados por indivíduos do mesmo sexo possuem uma vida familiar, constituem uma família. Assim, pode-se identificar uma tradição no sentido de expandir o conceito de família, primeiramente, para um núcleo formado não apenas pelo matrimônio, e posteriormente, para relações que não sejam baseadas apenas em laços heterossexuais, ilustradas a partir das citadas ressignificações efetuadas pelo Tribunal Europeu de Direitos Humanos.

Considerando o conceito de tradição à luz da hermenêutica de Gadamer, infere-se que esta possui uma autoridade anônima que atravessa os comportamentos dos indivíduos e as instituições, fazendo com que não se possam produzir compreensões livres de preconceitos e concepções prévias, por isso Gadamer considera que toda compreensão é preconceituosa. Atinente ao referido caráter penetrante da tradição e sua autoridade, partir-se-á para análise do conceito de família a partir dos conceitos hermenêuticos da situação hermenêutica, história efeitual e fusão de horizontes, à luz da hermenêutica gadameriana.

No que concerne à situação hermenêutica, deve-se buscar a consciência em relação à situação a qual o intérprete está inserido, mesmo que este ato de consciência nunca possa se concretizar integralmente. Trata-se do que já foi exposto anteriormente, não há como se definir a tradição, limitá-la, uma vez que o intérprete está inserido na mesma, logo o que pode ser realizado é tomar consciência da situação na qual o referido está inserido.

Logo, atinente ao caso em questão, deve-se considerar que a sentença em análise foi proferida em 24 de fevereiro de 2012, após todos os casos e resoluções expostos anteriormente. Assim, infere-se que a Corte Interamericana de Direitos Humanos, intérprete, 
ao analisar os fatos do caso Atala Riffo e Meninas Vs. Chile, estava inserida na tradição expansiva do conceito de família. Tradição esta, conforme ressaltado anteriormente, marcada pela concepção de alargamento do conceito de família, inicialmente pela consideração das relações não baseadas no matrimônio, assim como, posteriormente, pela abertura para a inclusão das relações formadas por casais do mesmo sexo.

Desta forma, a Corte Interamericana ao julgar o caso em questão, a partir dos seus fatos, estava inserida numa situação hermenêutica marcada por uma tradição expansiva do conceito de família, tradição esta, destaca-se novamente, indeterminável, uma vez que o intérprete está imerso na referida.

Ainda em relação à situação hermenêutica, pode-se analisar a consideração, pela Corte Interamericana de Direitos Humanos, de que a orientação sexual não representa uma causa de inabilidade para o exercício da guarda, ao considerar violador o afastamento das crianças do seu núcleo familiar, em razão da orientação sexual da mãe.

Neste contexto, pode-se identificar, também, que a tradição na qual a Corte estava inserida indica a referida consideração de que a orientação sexual não representa uma causa de inabilidade do indivíduo para cuidar dos seus filhos, principalmente através do caso X, Y e Z Vs. Reino unido, em 1997, que considerou entidade familiar a relação entre um transexual, uma mulher e uma criança, relação esta dotada de habilidade para que o casal exerça o direito de guarda sobre a criança, independente da orientação sexual de seus pais.

Assim, em relação à questão de inabilidade para o exercício do direito de guarda em razão da orientação sexual dos pais, pode-se ter consciência de uma tradição expansiva do conceito de família, citando-se, na sentença em análise, o referido caso do Tribunal Europeu em que se considerou família o convívio entre uma criança e pais que não seguiam a lógica heterossexual.

Considerando-se que a consciência da situação hermenêutica é o primeiro estágio da consciência da história efeitual, pode-se inferir que a compreensão do referido caso não pode deixar de considerar o corte histórico da própria compreensão. Assim, a situação hermenêutica deve ser considerada a fim de que se possa compreender o objeto histórico.

Neste sentido, os fatos próprios ao caso em análise não podem ser compreendidos apenas a partir da sua historicidade, uma vez se estaria limitando a compreensão, diante do entendimento de que os pontos questionáveis do objeto histórico são decorrentes da tradição e dos preconceitos. Assim, destaca-se que a Corte, ao analisar os fatos do caso em análise, 
considerou a historicidade do compreender histórico, a tradição expansiva do conceito de família na qual estava inserida, não podendo separá-la do objeto histórico a ser compreendido.

Desta forma, analisou-se o caso em questão à luz da situação hermenêutica em que a Corte estava inserida, realizando-se um intercâmbio entre o corte histórico do objeto e a situação hermenêutica, atravessada pelos casos do Tribunal Europeu de Direitos Humanos e resoluções da OEA e ONU.

Portanto, para a compreensão do caso em análise, a Corte considerou a situação hermenêutica em que estava inserida, marcada pela tradição expansiva do conceito de família, para analisar o objeto histórico, qual seja: os fatos ocorridos no período de 2002 a 2004, período este que corresponde ao momento em que a Sra. Atala começou a coabitar com a sua companheira na mesma casa onde moravam suas filhas e seu filho mais velho, até a decisão da Suprema Corte Chilena. Neste contexto, à consideração do compreender histórico, e não apenas da historicidade dos citados fatos, Gadamer chama de "história efeitual".

No âmbito da fusão de horizontes, a referida consideração da historicidade do compreender histórico se reveste no horizonte daquele que compreende, diferente do horizonte histórico, ao qual o intérprete pretende se deslocar. Assim, o compreender, para Gadamer, é o processo de fusão dos citados horizontes, o horizonte do intérprete, situação hermenêutica, marcada no presente caso pela tradição expansiva do conceito de família; com o horizonte histórico, representado pelos fatos ocorridos no período de 2002 a 2004.

Desta forma, ao se identificar na sentença em análise que a Corte Interamericana de Direitos Humanos condena o Estado do Chile pela violação do art. 11.2, referente à violação do direito à vida privada e, destaca-se, à vida familiar, proveniente do afastamento das filhas da Sra. Atala do seu núcleo familiar; assume a concepção expansiva do conceito de família, considerando que a relação formada pela Sra. Atala, sua companheira, suas três filhas e seu filho mais velho é uma entidade familiar. Tal concepção da Corte, conforme explanado anteriormente, é decorrente da própria tradição em que a mesma estava inserida, podendo-se analisar a relação entre a referida tradição e a concepção adotada pela Corte a partir dos conceitos hermenêuticos da situação hermenêutica, história efeitual e fusão de horizontes, analisados anteriormente.

Entretanto, deve-se ressaltar que os casos do Tribunal Europeu de Direitos Humanos citados não podem ser considerados precedentes do caso em análise, uma vez que não tratam especificamente do tema atinente ao presente caso, qual seja: o exercício do poder de guarda por um dos pais que possui um relacionamento com um indivíduo do mesmo sexo, e que coabita 
com o referido e o seu filho; tampouco as resoluções da OEA e ONU. Entretanto, através de tais casos e resoluções se pode identificar uma tradição na qual a Corte estava inserida, tradição esta que não é passível de delimitação, restrição.

Entretanto, destaca-se que a tradição na qual o intérprete está inserido não tem como definir qual será o futuro, a decisão a ser tomada. Neste sentido, foi uma escolha da Corte se posicionar da forma que se posicionou no presente caso, aplicando o que ela chama de “interpretação evolutiva”, baseando-se na ideia de que os Tratados são instrumentos vivos.

A referida interpretação da Corte, em relação ao caso em análise, pode ser relacionada, também, ao instituto da linguagem em Gadamer, no sentido de que entre a tradição, na qual o intérprete está inserido, e o próprio intérprete há uma conversação, um acontecer, que fundamenta uma experiência hermenêutica imprevisível.

Neste sentido, a conversação da Corte com a tradição, na qual ela estava inserida, ocasiona uma experiência hermenêutica singular, devido à própria historicidade do compreender. Assim, considerando que o modo de ser da tradição não é imediatamente sensível, mas lingüístico, no sentido de que é a linguagem que indica a tradição ao intérprete, pode-se considerar que toda interpretação é especulativa, uma vez que não se pode delimitar um “sentido em si” da tradição, tampouco da interpretação, que tem como objeto a referida.

Assim, através do caráter lingüístico da tradição, a Corte obteve uma experiência hermenêutica singular tanto em relação ao caso em análise, genericamente, mas principalmente, de forma específica, quanto ao conceito de família. Em relação a este, pôde-se interpretar os casos e resoluções pertencentes à tradição na qual estava inserida, proporcionando-se uma interpretação singular da sentença proferida pela Corte, no caso em análise, sobre o conceito de família, na qual se optou por considerar que a relação entre a Sra. Atala, sua companheira, suas três filhas e seu filho mais velho constitui uma relação familiar, uma família.

Portanto, a partir dos conceitos de tradição, situação hermenêutica, história efeitual, fusão de horizontes e linguagem; pôde-se analisar hermeneuticamente, à luz da hermenêutica gadameriana, a sentença proferida pela Corte Interamericana de Direitos Humanos, atinente ao caso em análise, no âmbito do conceito de família. Indicando-se, neste sentido, como os referidos conceitos hermenêuticos estão presentes no ato de compreensão da Corte em relação ao citado caso. 


\section{CONSIDERAÇÕES FINAIS}

A partir da análise da perspectiva fática do caso Atala Riffo e Meninas Vs. Chile, pôdese perceber que a discussão do direito de guarda da Sra. Atala, atinente às suas três filhas, está baseada na relação entre o instituto da família e o homossexualismo. Neste sentido, na concepção da Corte, a orientação sexual da Sra. Atala foi um elemento determinante para a retirada da guarda de suas filhas, por decisão da Suprema Corte chilena.

Neste contexto, a Corte Interamericana de Direitos Humanos considerou tanto o direito à Não Discriminação violado, como também o direito à Vida Privada e, destaca-se, à Vida Familiar. Assim, em relação ao conceito de família adotado, a Corte entendeu que a relação formada pela Sra. Atala, sua companheira, suas três filhas e seu filho mais velho, constituía uma relação revestida de natureza familiar, um núcleo familiar, uma vida familiar.

Seguidamente, partiu-se para a exposição dos conceitos hermenêuticos à luz da teoria hermenêutica de Gadamer. Trata-se da tradição, situação hermenêutica, história efeitual, fusão de horizontes e linguagem; determinantes para a realização da análise hermenêutica final da sentença proferida pela Corte Interamericana de Direitos Humanos, em relação ao caso em questão, atinente ao conceito de família adotado pela mesma.

A partir do referido substrato teórico, pôde-se realizar a análise hermenêutica acerca da concepção assumida pela Corte em relação ao conceito de família, identificando-se uma série de casos do Tribunal Europeu de Direitos Humanos e resoluções da OEA e ONU, organizados cronologicamente, representantes da tradição na qual a Corte estava inserida ao prolatar a citada sentença, destacando-se, neste contexto, a incidência dos conceitos hermenêuticos da tradição, situação hermenêutica, história efeitual e fusão de horizontes.

Por fim, ressalta-se que os casos e resoluções citados em tal sentença não representaram precedentes ao caso em análise, uma vez que não possuíam as mesmas especificidades do referido. Assim, a Corte através de sua concepção acerca da interpretação evolutiva, baseada na ideia de que os Tratados são instrumentos vivos, assumiu uma concepção acerca do instituto da família, incluindo neste a relação formada pela Sra. Atala, o que, hermeneuticamente, pôde ser relacionado à linguagem, considerando o acontecer entre o intérprete e a tradição. 


\section{REFERÊNCIAS BIBLIOGRÁFICAS}

DOUTRINA

GADAMER, Hans-Georg. Verdade e Método. Petrópolis: Vozes, 1997.

CONVENÇÕES E DEMAIS INSTRUMENTOS DE DIREITO INTERNACIONAL ORGANIZAÇÃO DAS NAÇÕES UNIDAS. Declaração sobre Direitos Humanos, Orientação Sexual e Identidade de Gênero, 2008.

ORGANIZAÇÃO DOS ESTADOS AMERICANOS. AG/RES. 2435 (XXXVIII-O/08), 2008.

AG/RES. 2504 (XXXIX-O/09), 2009.

AG/RES. 2600 (XL-O/10), 2010.

AG/RES. 2653 (XLI-O/11), 2011.

Convenção Americana sobre Direitos Humanos (Pacto de São José da Costa

Rica), 22 de novembro de 1969.

TRIBUNAL EUROPEU DOS DIREITOS DO HOMEM. Convenção para a Proteção dos Direitos do Homem e das Liberdades Fundamentais (Convenção Européia de Direitos Humanos), 4 de novembro de 1950.

JURISPRUDÊNCIA INTERNACIONAL

CORTE INTERAMERICANA DE DIREITOS HUMANOS. Caso Atala Riffo e Meninas Vs. Chile, sentença em 2012.

TRIBUNAL EUROPEU DE DIREITOS HUMANOS. Caso Alekseyev Vs. Rússia, sentença em 2010.

Caso Clift Vs. Reino Unido, sentença em 2010.

Caso Fretté Vs. França, sentença em 2002.

Caso J.M Vs. Reino Unido, sentença em 2010.

Caso Keegan Vs. Irlanda, sentença em 1994.

Caso Kroon e Outros Vs. Holanda, sentença em 1994.

Caso Kozak Vs. Polônia, sentença em 2010.

Caso Marckx Vs. Bélgica, sentença em 1979.

Caso P.B e J.S Vs. Áustria, sentença em 2010.

Caso Salgueiro Vs. Portugal, sentença em 1999.

Caso Schalk e Kopf Vs. Áustria, sentença em 2010.

Caso X, Y e Z Vs. Reino Unido, sentença em 1997. 